\title{
Gods, Demons, and Kings
}

In our analysis in the previous chapter we have caught a few glimpses of the relationship between kingship and the realm of the supernatural. In Han Feizi's manual and in Proclaiming harmony, royal authority is explicitly linked to the cosmic forces, and the downfall of King Zhou in The expedition of king $W u$ is partly due to the intervention of celestial deities and fox-spirits. The stories casually refer to magical objects, prognostic dreams, foretelling signs. In the Chinese and the Arabic/Persian narratives astrologers present their insights as matters of fact, convinced that the natural order is connected with the configuration of macrocosmic forces. Although these elements are not much elaborated upon-showing their common acceptance-they clearly suggest a link between supernatural forces of various kinds and human life in general and kingship in particular. The king is not merely subjected to these supernatural forces, like all human beings; he is part of them on a specific level and in some ways is used as an instrument by them or as a manifestation of them.

In his book The millennial sovereign; sacred kingship and sainthood in Islam, Azfar Moin argues that in Mughal India (1526-1857) and Safavid Persia (15011722) notions of kingship were modelled on Sufi and messianic patterns. ${ }^{1}$ Emperor Akbar (r. 1556-1605), in particular, juggled with religious concepts to construct his own religious myth of himself as a great sovereign and spiritual guide, connected with the Islamic millennial. This trend was initiated by Shah Isma'il in Persia, who also cultivated a kind of saintly status for the king as a messianic saviour. The incorporation of mystical and astrological elements into the definition of kingship in this period shows how Asian Islam developed its own concepts based on a religious undercurrent of popular beliefs and rituals inherited from ancient times. It shows the capability of embracing religious particularities caused by religious diversity within the empire, even to the extent that heterodox ideas were incorporated into syncretic belief systems. It also shows how discourses of kingship were constructed in such a way that they conformed to existing customs, traditions, and practices in order to appeal to and be accepted by the population. Existing religious concepts and practices

1 A. Azfar Moin, The Millennial Sovereign: Sacred Kingship and Sainthood in Islam (New York, 2014). 
structuring forms of authority were integrated into the process of transforming power into authority.

In the realm of Islam, the construction of kingship, or royal authority, along these lines is, of course, related to the historical decline of the worldly authority of the caliph, after approximately gooc.E., and the subsequent multiplication of sultanates all over the Muslim realm. Whereas the caliph had been and perhaps remained God's delegate on earth, enjoying the endorsement of 'official' religion, the sultans had to derive their status from the acknowledgement by the caliph and some form of religious legitimacy. This legitimacy could be sought either in doctrinal religion, striving for the purification of the faith and strict adherence to the legal prescriptions, or in an appeal to sentiments among the population based on indigenous customs and traditions, whatever their relationship with 'official' religion might have been. Or, and this seems more likely, the claims of kings may have been different in the various layers of discourses of kingship, exhibiting a more doctrinal attitude in official discourse, while a more syncretic image was spread within popular discourse. In both cases, literature would be an appropriate channel to convey the respective images, anchoring the idea of kingship in the collective imagination.

In this chapter we will examine some clusters of narratives characterized by the links between royal — and vizier's - authority and various kinds of supernatural forces, mostly related to popular beliefs about gods, demons, and spirits. These forces are a challenge for the prince, who has to prove his might in the face of these powers, often having recourse to the supernatural potential of the true faith. In this chapter we will discuss the Indian cycles of the legendary emperor Vikramaditya and tales of a similar type, especially the Thirty-two steps of the throne, together with the Harun al-Rashid cycle from the Thousand and one nights, and the Chinese novel Creation of the gods.

\section{The Prince and the Demons of Evil: The Legendary Vikramaditya}

It is a common feature of all literary traditions that narrative material tends to coalesce around certain historical or legendary figures. In Europe the main example is probably King Arthur, who, as a historical figure, became the centre of a large corpus of romances and mystifications. Another important example is, of course, Alexander the Great, whose adventures have become the nucleus of a vast array of narrative material that became popular from Europe to East Asia. Figures such as these tend to attract material that is not necessarily related to them, and they are not always the main protagonist; they are rather the centre organizing a corpus of stories that are mythologized and projected 
onto society, imparting them with their image and reputation. In this way their mythical image is preserved for the future together with the narrative material, which would otherwise perhaps have disappeared in the folds of history. Therefore, figures such as these are not only centres structuring discursive material, but also vehicles for texts, enabling and structuring their transmission. Apart from these functions, material of this kind can shed light on visions of kingship as they emerged in a specific time and were preserved and adapted within generic types.

In this section we will discuss two cycles of stories that have taken shape in different versions and forms and that show, first, the ways in which the ideal of kingship is related to specific figures that have thereby turned into a stereotypical persona, and, second, the way in which these figures combat evil that appears in the guise of demons, enchantments, or pseudo-enchantments. In these cycles we will find some narrative strategies that have been discussed in the previous chapter and several motifs that we have examined there. The device of the framing story comprising a chain of inserted tales is particularly prominent, as is the principle of dialogic exchange between the king and an 'adviser'.

\section{The Thirty-Two Steps of the Throne}

The narrative cycle of The thirty-two steps of the throne has been preserved in various versions, which not only represent the kernel of a narrative type, but also the syncretism of its development over time. It shows that this narrative material was transmitted over the centuries, in various languages, and remained relevant even in modern times. In the eighteenth century, manuscripts of the work were still circulating in India, and translations into French were made in 1817 and 1883 . The prototype of this cycle is probably the similar cycle The five-and-twenty tales of the genie (Vetalapancavinsati), which originated in the oral storytelling tradition and was incorporated into the large compilation Ocean of the streams of stories (Kathasaritsagara) by Somadeva (app. 1070). The most sophisticated version is the one by Sivadasa, which was compiled around 1300. It is embedded, of course, in the great Sanskrit tradition of storytelling, represented by the Mahabharata and the Ramayana, both treasuries of narrative material, figures, motifs, tropes, plots, and forms, and both a source for the oral and scriptural literary traditions.

The Twenty-five stories of the genie is a frame story in which the legendary beginnings are related of the kingship of Vikramaditya, the stereotype of the ideal monarch, who was a ruler, a warrior, a scholar, a patron of the arts, 
and, most of all, a man of compassion and self-effacement. ${ }^{2}$ In the frame it is disclosed that the stories of the cycle are told by Indra to his consort Parvati, the Mother of the Universe, and are overheard by Brahmana, who spreads them in the world. The cycle begins with the meeting between a yogi and King Ghandarvasena, who is enraged by the relentless silence of the sage and decides to send a prostitute to his abode to seduce him to speak. The ruse is successful, and a child is born, which is killed and cut into three pieces that are spread over the world. At the places where the pieces land three brothers are born simultaneously, and a prophecy holds that one of them will become the paramount ruler of the world. A sage visits Vikramaditya, the son of Ghandarvasena, and takes him to the cemetery to meet a yogi who needs his help. Vikramaditya has to carry a corpse hanging from a tree to the yogi, but he is not allowed to speak. However, the corpse is possessed by a genie, and every time Vikramaditya takes it on his shoulder, the genie starts telling him a story asking a question at the end. When Vikramaditya, inevitably, answers the question, the corpse returns to the tree and the procedure starts again. This is repeated twenty-five times. Finally, the genie tells Vikramaditya that the yogi intends to kill him, because then he will receive knowledge of the principles of kingship. Vikramaditya, thus warned, kills the yogi in a ritual fashion and receives the eight 'Perfections' granting him the supreme lordship of the earth.

The whole episode of Vikramaditya and the genie is meant to undo the harm done by his father Ghandarvasena, which brought a kind of enchantment into the world by violating the yogi's contemplative silence. The incentive of the king is, apparently, to have access to the realm of wisdom personified by the yogi, but his ruse is a contamination of the yogi's sanctity, associating him with foul, earthly affairs. The result is a scion filled with the lust for power, as if wisdom, unleashed by an evil trick, aims at nothing less than world dominance. It is Vikramaditya's task to lift the enchantment by ritually killing the vicious yogi; he thereby completes the cycle of an 'original sin' that results in the proliferation of evil, by showing that he is prepared to sacrifice himself to correct the course of events. In the process, he is initiated into the wisdom of the world and is thus educated as a future king, combining courage, compassion, judgement, and knowledge. He is now prepared to receive the eight 'Perfections': to be minute as an atom or enormous as a mountain, light as air or heavy as rock; to be invisible at will, to have all one's desires fulfilled; to subject others to one's will and to have rulership over the world.

2 Sivadasa, The Five-and-Twenty Tales of the Genie, trans. Chandra Rajan (London, 2006). 
The main motif, which sets the narrative in motion and which involves the various characters in an intricate intrigue, is, paradoxically, silence. It is the impregnability of the realm of wisdom, personified by the yogi, that causes the king's trespassing, and it is Vikramaditya's refusal to remain silent that prepares the way for the felicitous outcome. And it is the process of storytelling, in the liminal phase of Vikramaditya's trajectory towards kingship, that actually contains the wisdom that is the basis of sound rulership. Therefore, Vikramaditya's apprenticeship is not confined to a ritual, breaking a vicious spell; it consists, on the one hand, of his willingness to sacrifice himself and, on the other hand, of his sagacity, which, through the process of storytelling, results in a new equilibrium between power and wisdom and in the subduing of the destructive forces. Evil is contained not only by ritual, but also by narration and speech. His reward is the ultimate kingship: Vikramaditya is not merely a king; he is a portion of the Divine, born on earth; he will rule not only on earth, but also gain sovereignty in another sphere of existence. Siva says to him: 'A mighty lord, of my essence you are, a ray of light from me, born here, on earth.'3

The prominent role of storytelling, in the form of exemplary tales that contain a moral dilemma, draws attention to the dialogic nature of the narrative. As in the cycles analysed in Chapter One, the combination of a frame with inserted tales creates a dual vision of reality, consisting of a material and a discursive component, and revealing the hidden layer of meaning within a specific sequence of events. This hidden layer in the end provides the key to the solution, but it has to be 'unearthed' first. The dialogic structure of the narrative is embedded in the fictional intrigue in the frame story, with, on the one hand, the failure to establish communication and, subsequently, the exchange between Vikramaditya and the genie. It is the establishment of a dialogical situation that creates a balance between events and interpretation, between power and wisdom. In the end, after the felicitous outcome, the king states his wish: 'Grant that this work, The five-and-twenty tales of the genie may become celebrated and gain renown. By your grace may this genie be my minister and carry out my edicts!' ${ }^{4}$ Finally, even the genie takes off his mask and turns out to be a common vizier.

The lore of Vikramaditya's ascent, which made him the prototype of the just and wise king, is also part of the prehistory of the cycle Les trente-deux récits du trône. As The twenty-five tales of the Genie, this cycle is a frame story

3 Ibid., 181.

4 Ibid. 
containing exemplary stories set in a frame in which the origin of the cycle is explained and enacted. The main character is Bhodja, a historical king who lived in the fifth century C.E. and who acquired wide fame for his wise rule. It is told in the framing story involving a throne, found on a farm, that can be taken to the royal court only after a solemn ceremony. As the king tries to climb the steps of the throne, he is halted by a genie, who tells him the history of the throne: In the town Avanti the king offended his brother Vikramaditya, who left the country and started roaming the world. After the death of the king, everyone who succeeded him was immediately killed by a vicious genie (vetala). Vikramaditya returned to the court and became king, escaping death by preparing food for the genie every day. At a certain point he asked the genie whether he would be capable of adding or subtracting one year from his (Vikramaditya's) life. When the genie answered that he could not, Vikramaditya attacked and subdued him. After this episode, Vikramaditya's adventure with the evil yogi follows, resulting in his receiving the divine throne from Indra, embellished with thirty-two statues on thirty-two steps. When he seats himself on the throne, he is endowed with the virtues of Indra: heroism, energy, activity, intelligence, science, firmness, profundity, and severity. After his death the throne remains empty, because nobody is worthy of it.

After this introductory tale, Bhodja ascends the throne, but he is stopped by the genie of the first statue, on the first step, who tells him a story containing some meritorious instruction. This continues until after thirty-two steps/stories Bhodja is allowed to climb all the steps. As in the cycles discussed above, the stories told by the genies are exemplary tales in the sense that they present some wisdom or moral dilemma or model of virtue and justice. They illustrate the nine states of the soul and the eight vices. An important element is the supernatural powers attributed to objects such as magical shoes, or talismans, or 'Mulika', an object that fulfils wishes; and to demons, such as the Raxas, which are anthropophagous, and the Nagas, which are snakes living in water underground. Another magical element is metamorphosis, characters assuming different appearances usually in different lives. A curious 'realistic' tale relates the working day of the king Vikramaditya: He wakes up to the accompaniment of music and singing; then follows time for meditation and prayer; the girding of the royal weapons and insignia; giving presents to the counselling and executive ministers and other sages. Midday: fulfilling the prescriptions of the Veda and giving alms to the sick and the poor; a meal with parents and friends and allies; four courses in six tastes; taking betel; washing with aromatics (sandal); a nap; enjoying birds, parrots, flower festoons; having fun with young women; listening to stories; inspection of the troops, treasures, and 
landed possessions, with the inspectors; ceremonies prescribed by the Vedas with the Pandits according to Castras; entertainment, music; permitted unions (?); sleep.

In another, Persian, version of the Trente-deux marches du trône, Rajah Bhodja consults the stars and attempts to climb the throne. ${ }^{5}$ Suddenly a swarm of thirty-two big bumblebees appears, morphed genies sent by God to guard the throne, since it can be occupied only by someone who is as virtuous, good, and disinterested as his predecessor Vikramaditya. Every time Bhodja wants to climb another step, he is stopped by a genie who tells him a story of the great magnanimity, altruism, and goodness of Vikramaditya, obviously to instruct the rajah during his ascent to kingship. Each story contains an example of some virtue, such as controlling one's anger, self-sacrifice, generosity, forgiveness, prudence, courage, magnanimity, sound judgement, consideration, alertness, trust, etc. In most cases some moral dilemma must be solved or cases of extreme generosity, altruism, or courage are expounded. Several stories are known from other cycles, not only other versions of the Thirty-two steps, but also collections such as the Sukrasaptati, or the Tales of the parrot, and some motifs even reached the Thousand and one nights in some of its versions.

In a typical story, Vikramaditya sends inspectors out into his kingdom to report on the conditions of the people. One of them returns and reports that he passed by a temple on a mountain next to a lake haunted by a genie. Whoever entered the water and was virtuous came out covered with white spots; when a sinful person entered the water he came out covered with black spots. Vikramaditya, curious, sets out to explore this phenomenon. He enters the lake and is covered with white spots. At the same place he meets a Brahmin who has to atone for some sin he has committed; he will be pardoned only when he has bathed in the blood of a rajah. Vikramaditya immediately seizes his sword and cuts off his own head, but at that point the good genie Behekouty intervenes and saves him. This is only one of many examples of situations in which Vikramaditya is willing to sacrifice his life to undo some kind of spell imposed, mostly, on a person or a place. Usually he is rescued by Behekouty and rewarded for his altruism. ${ }^{6}$

In another story (XIII), which is instructive as a guide for kings, Vikramaditya wants to inspect his empire. He sets out incognito, dressed as a djogui (yogi), with the intention to gather 'certain and uninfluenced' information about

5 Les trente-deux marches du trône ou comment mériter le pouvoir, trans. Daniel Lescallier (Paris, 2014).

6 Ibid., 77, 83; stories VIII, IX. 
everything affecting his government and to check that his mandataries do not abuse their power and commit injustices. At one point he overhears a conversation about a city on an island governed by a djinn who has demanded that a temple be built for him where a man is sacrificed every day. Vikramaditya travels to the city on his magic chair and offers himself as the next victim. When the genie arrives, he shows no fear and converses with the genie about his bad habit, showing pride that he is to be eaten by such a noble person. The genie finally repents and promises that he will refrain from eating human flesh in the future.

Some stories are directly related to Vikramaditya's status as a king, for instance in story XIX when a Brahmin tells him that he has visited a temple of Shiva at the seaside. Every day a golden column rises out of the water with a throne on top of it. At sunset it disappears again. Vikramaditya journeys to the place and sees the column rise up out of the water. He flies towards it on his magic chair and sits down on the throne. Since the sun is burning hot, clouds are sent to protect him and water from the source of life. Honoured, Vikramaditya thanks the sun and receives a talismanic ring that the sun has taken from its own ear. Later, Vikramaditya roams his capital in disguise and presents the ring to a poor Brahmin on the street. This story, of course, aims to confirm the semi-divine status of Vikramaditya's kingship, which is acknowledged by the Supreme Being. At the same time, it emphasizes his humility and generosity, and his lack of desire for material gain.

Vikramaditya's humility is confirmed in several other stories, such as the story of a rajah who is too assiduous in his religious duties and neglects the affairs of the state. He is expelled by genies who support his successor, who is less extreme in his religiosity. This is reprehended, although it is stressed that the turn of events reflects the will of God:

Vous voyez par cet example que tout ce qui existe dans le monde est un effet de la volonté de Dieu qui peut à son gré faire d'un rajah un infortune; et mêttre sur le trône un indigent.—J' en suis plus que jamais convaincu, répondit le rajah, j' ai toujours été persuadé que les souverains sont comme les autres hommes, sujets comme eux aux vicissitudes du sort; qu' ils ne peuvent obtenir le respect et la consideration qu' en remplissant avec exactitude les devoirs nombreux qui leur sont imposés et en faisant le bien. ${ }^{7}$

7 Ibid., 151, story XVI. 
Apart from this recognition of God's supremacy, Vikramaditya also recognizes the importance of respect for the labours of the common people:

Un rajah ne doit jamais perdre de vue que les sommes dont il dispose sont le produit des sueurs de son people et ne doivent être employées que pour le bien de l'État. Ce rapport essentiel entre le gouvernement et les gouvernés, ce lien intime de confiance et d'attachement réciproques entre eux cesseraient si celui-ci avait la faculté de se procurer sans eux et par un moyen étranger et extraordinaire tout l'or qu'il pourrait desirer, et l'honneur serait perdu. ${ }^{8}$

Clearly, the position of the rajah is somewhere between the celestial powers and the common people, subjected to the will of God, but endowed with the ability to conjure the spirits of evil, with the aim of stabilizing the prosperity of the populace. In one of the stories, the seven good properties of a king are symbolized: life and health, sound judgement, prudence and wisdom, a filled treasury, military arts and a strong army, prospering agriculture, and steadfastness. $^{9}$

The intermediary position of Viramaditya between the gods and the people is highlighted by his ability to subject spirits and his systematic renunciation of the magical objects he receives for his noble deeds, such as magical rubies or rings that bring worldly profits. He is concerned with piety and serving God, but he is also preoccupied with the practical welfare of the people, which is threatened by evil demons or cruel enchantments. It is worth noting that the religiosity in the Persian version of the cycle shows a gradual shift. Whereas the Bengal version is clearly a reflection of the Hindu cosmology and mythology, in the (later) Persian text we find more references to typically Islamic phenomena, such as houris (the virgins in paradise), the term darwish, in addition to yogi, and even the pilgrimage to Mecca. ${ }^{10}$ As we will see, this intermingling of Hindu and Muslim elements was by no means an exception in Indo-Persian literature, and it shows how at a specific level certain concepts, practices, rituals, and figures from one religion could easily be accepted within the imaginary of the other religion. In particular, the motifs of the genies, the enchantments, and the subjugation of magical forces appealed to the general audience, regardless of its religious affiliation.

$\begin{array}{ll}8 & \text { Ibid., 54, story v. } \\ 9 & \text { Ibid., } 256 . \\ 10 & \text { Ibid., } 102 .\end{array}$


In several respects, the cycle of the Trente-deux marches du trône is a logical sequel to The twenty-five tales of the genie. It is less archetypal, but it has retained the specific, formal procedure. It has evolved through history and has perhaps become diluted, but it has also assimilated elements from new environments. Both cycles show similarities with the cycle of the Seven viziers and its cognates. The dramatic intrigue is caused by a rupture-in the case of The Twentyfive tales involving a licentious woman - and in the end the restoration of harmony is achieved through a combination of ritual and narration, itself representing the result of this process: the embedding of power in a setting in which storytelling symbolizes the medium of rationality and of conjuring disorderly forces. And here, too, this medium is engendered by situations of dialogism, between the sage and the king, between the demons and the king, and between reality and the imagination. The aim in the end is a combination of initiation and conjuration, in order to install a harmonious structure of authority, endorsed by God and without undue interference by supernatural forces.

\section{Harun al-Rashid, Vizier Ja'far, and the Jinns}

In his study of the Arabic tradition of kingship Aziz al-Azmeh argues that discourses of authority, especially concerning kings, caliphs, and sultans, can to a large extent be found in works within the genre of the mirror-for-princes. Whereas treatises on the political and juridical aspects of kingship are relatively rare, the codes of conduct for kings, guidelines for government, and general principles for the legitimation of rule are often expressed in semi-fictional handbooks, either treatises including literary elements or literary works containing practical wisdom. ${ }^{11}$ This observation suggests that in the Arabic literary tradition there is a strong connection between authority and narration, based on a similar connection in the Sanskrit and Persian traditions of wisdom literature. It seems that this convergence of fictional narratives and discourses of authority is not merely a question of generic categories, but rather a deeply felt sense of symbiosis between the essences of authority and the imagination. This is confirmed by our findings above, in connection with the cycles of the Seven viziers, 'King Jali'ad', and The twenty-five steps.

11 Aziz al-Azmeh, Muslim Kingship: Power and the Sacred in Muslim, Christian and Pagan Polities (London and New York, 1997) 89-93. 
In Arabic literature, one of the rulers who attracted the attention of storytellers and literati is Harun al-Rashid, the historical caliph, who became the subject of many anecdotes in $a d a b$ - highbrow - literature and of several stories incorporated in the early and later versions of the Thousand and one nights. It seems that he came to represent the glorious days of the 'Abbasid caliphate, with its connotations of prosperity, cultural refinement, intellectual and artistic progress, and religious orthodoxy. Although the status of a caliph differs from that of a king, as 'commander of the believers' rather than as the ruler of a state, he came to represent a quintessential conception of Islamic rule, including originally Persian elements of kingship, bureaucracy, and court life. His rulership therefore contained both secular and religious components legitimizing his privileged position, although, especially in Harun al-Rashid's time, it was clear that the caliph was bound by religious law like all his subjects. It is probably his combined religious and worldly attributes that made him attractive for storytellers and authors as a subject for their portrayal of an 'ideal' prince, comparable to Vikramaditya and others in the Indian and Persian traditions.

Here it is not my intention to study the way in which the historical figure of Harun al-Rashid is represented in Shahrazad's stories, but rather to examine how a perception of 'kingship' is construed through the association of authority and storytelling by staging Harun al-Rashid as a character in the stories and as a ruler. Can the interaction between storytelling, or, more broadly, the imagination, and authority, as presented in the cycle of the Seven sages be perceived in the Harun al-Rashid stories as well? And, our main concern in this chapter, how is the interaction between the caliph and supernatural phenomena incorporated into the stories to strengthen his claims to kingship? We will zoom in on the two stories of the 'Porter and the three ladies of Baghdad'12 and the story of the 'Mock caliph.'13 The first of these two stories is part of what is commonly held to be the original 'core' of the Nights and is thus firmly linked to the framing story, while the philological status of the latter story is still unclear, although a version of it can be found in the work I'lam al-nas by al-Itlidi (seventeenth

12 For a summary of the stories and references to analyses, see Marzolph and Van Leeuwen, The Arabian Nights Encyclopedia; A Plain and Literal Translation of the Arabian Nights Entertainments, Now Entituled The Book of The Thousand Nights and a Night, trans. Richard Burton, 10 vols. (s.l., s.d., [Burton Club, 19o5?]) vol. 1, 82-186.

13 Marzolph and Van Leeuwen, The Arabian Nights Encyclopedia, vol. 1, 304-305; A Plain and Literal Translation, vol. 4, 130-148. 
century). ${ }^{14}$ It was incorporated into the Thousand and one nights in the Egyptian versions of the eighteenth century. ${ }^{15}$

The Harun al-Rashid stories that are included in the Thousand and one nights can be divided into three groups: first, the anecdotes situated at the caliphal court in Baghdad, often including other famous historical persons, such as Zubayda, Abu Yusuf, and Abu Nuwas; second, the stories in which Harun alRashid plays a nominal role, only to effectuate the plot, as a personification of authority or a deus ex machina; and, third, the stories in which he is a character participating in the deployment of the narrative or even sets the narrative in motion. The anecdotes of the second category are presumably taken from adab texts and are clearly different from the main type of stories collected in the Thousand and one nights. They give us a picture of Harun alRashid as a narrative persona, portraying him as an absolute ruler who is rather impulsive and naïve and who is implicated in various comic intrigues typical of a royal court. The second type of story is also of significance, since it stresses the absolute power of the caliph, but links it to an inclination to clemency and justice. Here, too, the humorous side of Harun al-Rashid, which became a topical feature of his persona, is emphasized. In our discussion it is stories of the third type that are most relevant, since they show Harun as a more complex narrative 'construction', including the trope for which he became especially famous: his nightly excursions to inspect the conditions of his subjects. ${ }^{16}$

The first story to be analysed here is the complex narrative of the 'Porter and the three ladies of Baghdad'. In this story a porter is hired by a lady to carry all kinds of foodstuffs and party equipment to a luxurious mansion, which turns out to be owned by three young ladies, who intend to have a party that evening and allow the porter to attend. As the party develops, three mendicant dervishes are allowed to come in and, somewhat later, Harun alRashid, his vizier Ja'far, and his swordsman Masrur, dressed as merchants, join the company. They are all admitted into the house on condition that they do not ask questions about what they see, as is indicated in a verse above the entrance. At a certain point one of the ladies brings in two dogs from another room and starts whipping them, but she consoles them afterwards. Eventually the two other ladies start lamenting and show their bodies, which are covered by scars.

14 About al-Itlidi and the Thousand and One Nights, see Marzolph and Van Leeuwen, The Arabian Nights Encyclopedia, vol. 2, 606-6o7.

15 Ibid., vol. 1, 304-305.

16 See entry 'Hârûn al-Rashîd', in Marzolph and Van Leeuwen, The Arabian Nights Encyclopedia, vol. 2, $585-587$. 
At this point, the porter cannot control his curiosity and asks what the strange scenes mean. Angry at this impertinence, the ladies summon seven black slaves to kill the visitors, but before being killed they have to tell their lifestories. The dervishes tell their strange adventures, and Ja'far tells a concocted story, after which they are all released. The next day the caliph, restored to his true identity, has all those involved in the events taken to the palace and asks the ladies to tell their stories. It appears that the dogs are two envious sisters of the eldest lady who were turned into dogs by a spell. Harun summons the jinniyya responsible for the spell and commands her to lift it. The other two ladies turn out to have been the victims of unfaithful husbands. Harun subsequently solves all problems and restores normality. ${ }^{17}$

As the summary shows, the story of the 'Porter and the three ladies' has some basic similarities with the framing story of the Thousand and one nights and with the Seven viziers. It is constructed as a frame story, with embedded stories, and linked to the 'ransom motif', that is, to storytelling to avoid a seemingly certain death. Here the story is not triggered by a traumatic event of adultery, but in the end it becomes clear in the stories of the ladies that the events that have led to the death threat were in fact caused by unfaithfulness and disloyalty. This unfaithfulness has resulted in the ladies having to survive on their own and their retirement together to a separate household. This, of course, is a social anomaly, which is buttressed by the strange ritual of punishing the enchanted dogs. To hide this curse, the ladies have constructed their space as a separate domain in which visitors are restricted to obedience and can speak only to a certain limit. As in the case of the framing story, the tension between the sexes has led to a stagnation of the normal course of events, which is preserved by a kind of ritualized spell. It is the act of storytelling that in the end reveals the secret behind this anomaly and that enables Harun to set things straight and restore life to its normal course.

Another similarity between the story and the framing story is the state of liminality caused by the events — especially the enchantment — and into which Harun al-Rashid is drawn. To be sure, he is not forced to become involved, but is rather prompted by his own curiosity. The act through which he enters the liminal status is his disguising himself as a merchant, which enables him to throw off the decorum of sovereignty and mingle with the common people. It enables him to bridge the gap between his absolute authority and the essentially powerless subjects. This creates the prerequisite conditions not only for any form of communication, but also for a negotiation required to comprehend and finally 
counter the anomalous situation. After all, it is not simply storytelling, but storytelling to solve a predicament that ultimately leads to the denouement. It should be noted here that although by disguising himself Harun throws off the externalities of his authority and exposes himself to potential dangers, he does not relinquish the 'material' supports of his power, represented by Ja'far and Masrur. Once Harun has resumed his normal position and the relationships of authority and subservience have been restored, he can enforce an end to the state of liminality.

Before we proceed with an evaluation of the character of Harun al-Rashid in this story, we will first discuss the second story in which Harun al-Rashidor even two Harun al-Rashids-plays a major role. In the story of the 'Mock caliph', Harun al-Rashid sets out at night to inspect the city, with his vizier and executioner, disguised as merchants. When they want to make a boat trip on the Tigris, they are warned that the caliph is accustomed to take a boat trip every night and has threatened to have anyone who ventures on the river beheaded. After a while they see a boat approaching with a stranger in caliphal robes, sitting on a throne, in the company of men dressed as Ja'far and Masrur and other court dignitaries and drinking companions. Eager to find out the secret of this impersonation of the caliph, the next night they furtively join the company, which enjoys a luxurious banquet in a palace on the shore. At a certain point, when a love-poem is sung by a slave-girl, the host, dressed as the caliph, tears his robes from his body and shows scars of whipping. It turns out that the mock caliph is a jeweller who was married to Ja'far's sister, but was unjustly repudiated by her. From that moment onwards, he had assumed the role of caliph every night. The next day Harun summons the estranged couple to appear before him and reconciles them. ${ }^{18}$

Even in this brief summary some by now familiar features stand out. First, the ill-fated love-story that leads to a strange, anomalous situation, perpetuated through ritual-like behaviour; and, second, the caliph entering a liminal situation by disguising himself and mingling with the common people. Finally, although the ransom motif is less conspicuous, it is present in the death threat against anyone 'trespassing' on the Tigris, forcing the caliph to follow and join the party of the mock caliph unnoticed. In the end it is the telling of a lifestory, embedded in the main story, that brings about the satisfying outcome of the adventure. Apart from these characteristics, which link the story both to the framing story and to the story of the 'Porter and the three ladies', the motif 


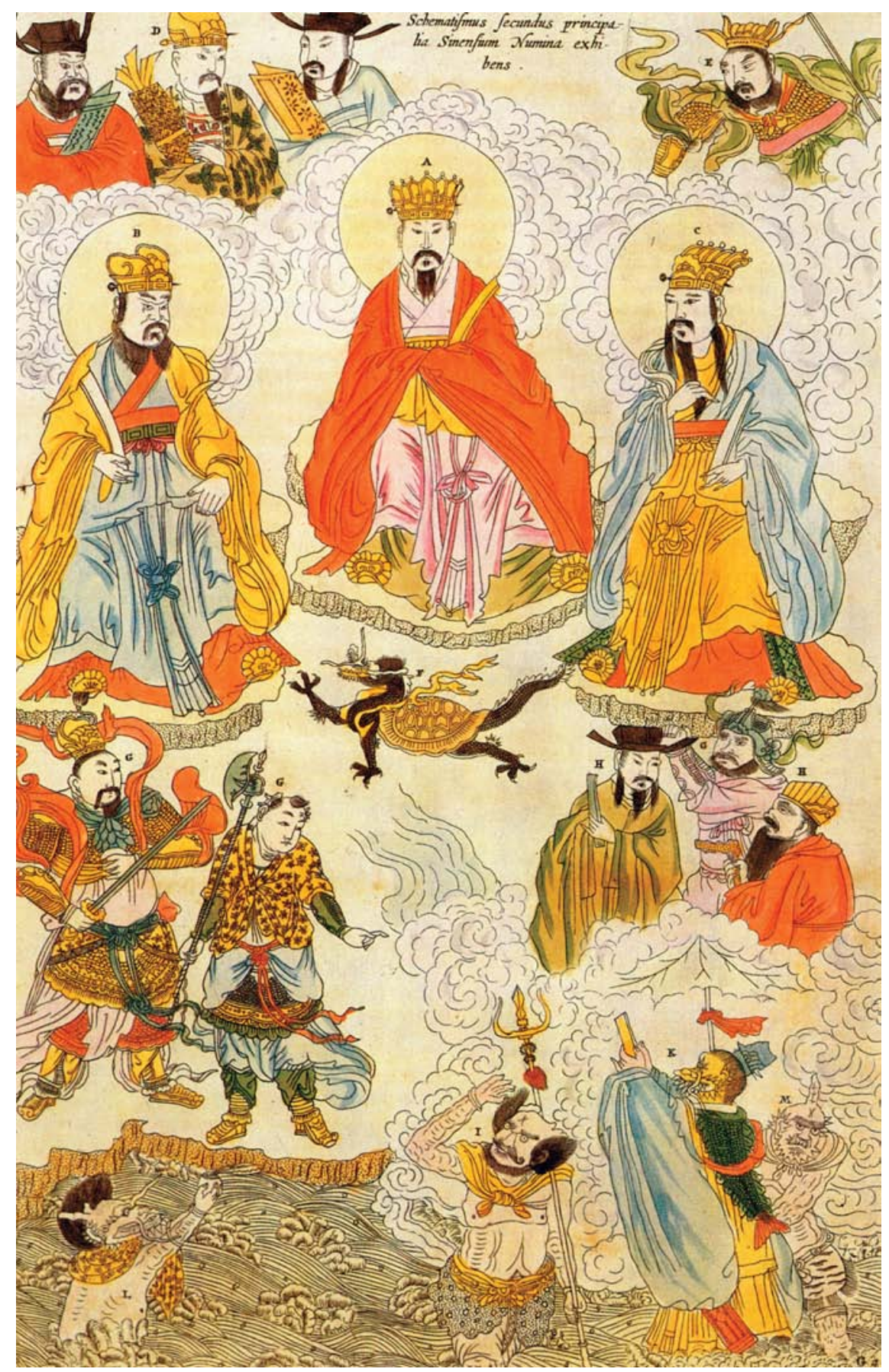

FIGURE 3 Chinese pantheon, by Athanasius Kircher (1667). 
of the whipping and wailing as a result of unrequited love strengthens the links with the latter story, both structurally and thematically.

The most distinguishing characteristic of the story of the 'Mock caliph' is, of course, the figure of the false caliph, acting as a mirror-image of Harun alRashid. The motif of the body-double can be found quite often in the Thousand and one nights, and it is prominently present in the framing story, which is marked by the symmetry between Shahriyar and his brother and between Shahriyar and the black slave pleasuring the queen. In the latter case the motif is linked to the question of authority: the black slave is the antithesis of the king and by being his 'mirror-image' either reduces the authority of the king to a mere trifle, or proves that the king is essentially no better than a hideous, lustful servant. Both possibilities show Shahriyar that because of the presence of his wife - the element of passion and chaos-his authority is not vested in the symbolic, institutional authority connected to the kingship and his masculinity, but rather in his bodily presence, falling apart as soon as he is away from the palace. This reveals both the complexity and the fragility of royal authority.

A similar discovery occurs in the story of the 'Mock caliph', where the mirror is not so much spatial — the king leaving his palace, divesting it of his royal authority-, but temporal, according to the dualism of day and night. During the day everything follows its regular course, but at night the caliph dons his royal garb, detaches himself from the externalities and paraphernalia of his power, and is absorbed by the 'common people', only to be confronted with his nocturnal antithesis, who has usurped the royal prerogatives to dominate the space of Baghdad with his threat. Rather than the 'physical' absence of the caliph, it is the 'symbolic' absence of the caliph that allows the false caliph to take his place, just as it is not the physical but rather the symbolic prerogatives of the sovereign that he usurps, the power that emanates from the paraphernalia and externalities. This is achieved by evoking a situation of make-believe, a performance and the effectuation of a fantasy. It should be noted that, of course, the real caliph, disguised as a merchant, is performing a role as well, completing the fictional character of the scene.

It is the existence of his body-double that forces Harun al-Rashid to act in order to redress the anomalous situation, because it is a situation that cannot be tolerated, as is cleverly foreseen by the false caliph: the only one who will dare to uncover him will be the real caliph, who, on that occasion, will be obliged to deal with his problem in a discreet way. It is suggested, therefore, that even imagined authority can be effective, that a performance has the power to change the course of events and enforce a specific outcome. 


\section{Harun al-Rashid and the Discourse of Power}

As becomes clear in the analysis above, there are many formal and thematic links between the two Harun al-Rashid stories and the framing story of the Seven viziers, linking them to the concept of authority, which is expressed in the framing story and the mirrors-for-princes as a discursive genre. Moreover, the stories fit very well into the genre and conform to Shahrazad's purpose in telling the stories: they show the nature of power, its being curbed by rational decisions, and its complexity. As such they have an instructive and didactic value and refer to the same thematic complex as far as authority is concerned, as does the framing story, presenting examples of the sovereign confronted by an anomalous situation, which he has to judge and solve in a rational way. In this sense, Harun al-Rashid is the typical sovereign, with absolute power, and implicated in stereotypical roles. In his narrative guise, he has become a quintessential ruler within the discourse of authority.

Of course, the actions of Harun al-Rashid are not instigated by some 'classical' trauma, as in the case of the cuckolded kings. Harun is usually prompted by curiosity, which suggests a basic dualism in his mind and uncertainty about the effectiveness and effects of his absolute power. To a certain extent, his royal power distances him from 'real life', forcing him to temporarily cast off his caliphal dignity with its social and spatial barriers. This curiosity is, of course, a prerequisite for the potential of Harun al-Rashid as a narrative figure himself, or his character, being a source of narrative dynamism opening up the space for storytelling. His curiosity, as a literary element, is nicely exploited in both stories: when in the house of the three ladies curiosity is explicitly forbidden by the verse above the entrance, thereby establishing a specific relation of power heightening suspense and foreshadowing the course of events, and when the caliph asks the boatman to approach the barge of the false caliph, he being in the light and we in the dark, so that we can look at him without him being able to see us,' elegantly buttressing the antithesis between the two caliphs of the night and of the day.

Although the stimulus of the story is not a traumatic experience suffered by Harun al-Rashid, it is in fact traumatic experiences that are the underlying spur to the story as a whole. As in the case of the framing story of the Seven viziers, these experiences are related to rejected love, the struggle between the sexes, and the perfidy of passion, thereby linking issues of sexuality to the discourse of power. In the case of the three ladies it is the unfaithfulness of men and the jealousy of women that have led to the socially exceptional situation of three ladies living an isolated life together outside the custody of men. It is this anomaly that provides the narrative potential in which Harun 
al-Rashid's peculiarities are deployed. Although it seems that because of their 'curse' they have established a feminine authority within their domain, the message of the story is not overly feminist, since it is especially herein that lies the anomaly that Harun al-Rashid has to resolve. However, this motif parallels the story of the 'Mock caliph', in which an aborted love leads to an 'enclave' of alternative imagined authority within society, forcing the ruler to respond, a situation similar to Shahriyar's anti-female regime that leads to stagnation and ruin. In the case of Shahriyar the physical act of a woman destroys the symbolic authority of the king, whereas in the story of the 'Mock caliph' the harshness of a woman brings forth an-admittedly imagined - symbolic authority in a man. In both cases it is suggested that women, or perhaps more correctly, a harmonious relationship between men and women, are the key to the integrity of authority, amalgamating its physical and symbolic components.

In the Harun al-Rashid stories a deconstruction of the stereotypes of power takes place, made possible by the caliph's disguise and his wish to remain incognito. In both cases he willingly subjects himself to women, the quintessence of irrationality, and to someone who impersonates him and whose claims to authority must inevitably be false. In both cases he takes the risk of being killed, a risk enhanced by his impulsiveness, his naivety, his curiosity, and his difficulty in maintaining his disguise. As has been remarked above, however, the risk is reduced because Harun has himself accompanied by Ja'far, who constantly tries to avert dangers by giving sensible advice, and Masrur the executioner. As in the case of the framing story, the inversion of roles is connected to the situation of liminality into which the caliph enters and which is part of a renegotiation of relationships, which may lead to a solution of the dilemma, for instance through the telling of life-stories and the uncovering of hidden intrigues. Only through entering a liminal situation and finding an imagined form to express the underlying trauma can authority be mobilized to resolve the anomalous situation, going through a phase of make-believe and temporarily assumed roles.

In the Harun al-Rashid stories, the caliph is presented as a stereotypical figure, both as a narrative character, and in his association with the general type of the absolute sovereign. In the story of the 'Three ladies', which we know only in the context of the Thousand and one nights, it seems justified to say that this narrative characterization of Harun al-Rashid was consciously used to comment on power relations as imposed by the framing stories on the embedded stories, strengthening the idea that narration and imagination are an integral part of discourses of power and their critique. This conclusion is supported by the way in which narration and imagination have their roles in the stories themselves, hiding and ultimately revealing an underlying reality containing 
the rationale of events and enabling the ruler to exert his authority in a rational and just way. The suspension of disbelief, in its various appearances, seems to be indispensable first to deconstruct claims to authority, but ultimately to preserve them. This is a dualism inherent in the nature of power, as it is in the negotiations between women and men.

If we compare the cycle of Harun al-Rashid with the cycles of the Seven viziers and the Sanskrit cycles, we can hardly avoid the impression that they are part of a single tradition. This tradition combines instructions for the prince with storytelling and has a preference for the frame story as a narrative structure to link the different levels of the narrative. In all cases the reader is gradually introduced to idealized forms of kingship, either in the form of an abstract king-protagonist, or as an abstraction of a historical or legendary figure. Vikramaditya and Harun al-Rashid have become stereotypes representing the values inherent in good rulership, deriving their status both from the traditional conventions and their own personal intervention in the affairs of the empire. They both attain the culmination of good kingship: they are prepared to sacrifice their lives in order to save the lives of their subjects or to avert the evil intentions of demons. The common motif of the inspection of the conditions of the subjects in some kind of disguise, with the aim of gaining objective, unmediated, and unprejudiced knowledge about the situation of the empire, is a significant feature of both cycles. This fictional element provides the discursive link between the high status of the king/caliph and the common people, making possible the acceptance of the extraordinary position of the king/caliph among the people. It also displays the two components of the king, as an institution bound to formal rules, and as a person driven by his impulses and moral inclinations.

A remarkable topos in the various cycles is the motif of silence. In the cycle of the Seven viziers the prince was not allowed to speak for ten days to avoid certain death. In that stretch of time the viziers exhibited their wisdom and the prince completed his transition to a fully grown ruler. This suggests that there is a taboo on speech within the transition ritual, necessitating the explication of the discursive field surrounding the process of succession to the throne: The conventions and threats are reiterated, even resuscitated and conjured to re-institutionalize the principles of government as dissociated from the 'subjective' influence of the ruler in spe. The prince is not an actor in the process, but rather an object that has to be moulded and fitted into the system. It is the silence of the prince, imposed by the macrocosmic forces, that obliges the other protagonists to speak.

In the Sanskrit cycles the motif is also related to esoteric knowledge, contemplation, and the realm of the gods and his sages. Here, too, speaking is taboo, 
a desired 'object', because it contains and hides some indispensable wisdom needed for earthly harmony, and here, too, the taboo is violated by the contamination of the 'pure' state of silence with the lure of carnal pleasure and feminine perfidy. It is women who pose the greatest challenge to sacred forms of silence and who represent the element of profanity and indulgence in material/physical pleasures at the expense of spiritual or mental well-being and correctness. In the Harun al-Rashid cycle, in the story of the 'Three ladies of Baghdad', we again encounter the ban on speech, at the risk of execution, which leads to a bizarre, incomprehensible spectacle. Harun al-Rashid is not allowed to ask questions, but when he cannot contain his curiosity and speaks, he is 'punished' only by the obligation to tell his life-story. Here, as in the other cases, the resolution of the taboo on speech is achieved by narration in various forms, by telling stories that both contain and convey hidden wisdom and hidden explanations. Silence represents a stalemate, whereas narration indicates movement and continuity, both by exhibiting certain topics and by establishing a process of communication.

\section{Fighting the Evil Spirit: Creation of the Gods}

The stories of Vikramaditya and Harun al-Rashid show that kingship is intimately related to forces in the supernatural realm, in the form of demons, magical objects, and spells, and that the legitimation of kingship is partly derived from the prince's ability to bring harmony to the relationship between these forces and the population of the empire. This process is not governed by the king himself, but is dependent on the more powerful will of God, in His various guises, which finds expression in fate. This complex process is perhaps most intricately imagined in the Chinese tradition, which developed a dynamic vision of the all-encompassing interrelationships between human life and the cosmic forces, represented by a vast array of gods, spirits, demons, immortals, proto-immortals, etc., each with specific functions, abilities, and authority. Life on earth is permanently in contact with the realm of the supernatural, which time and again intervenes to fulfil the directives of fate and to preserve the balance of forces that regulates both realms. This vision is, of course, taken mainly from the imaginative mythologies of Taoism and Buddhism.

The rich representations of the supernatural realm are most vividly described in the Chinese literary tradition and more specifically in several great novels that appeared from the sixteenth century onwards. Most of these novels and romances were based on accounts of historical figures and episodes, which were enriched by popular lore and spurious material accumulated in the liter- 
ary tradition. Some of these novels are more realistic than others; some clearly indulged in supernatural extravaganza, while others were more restrained. In most cases, however, the stories were in one way or another connected with rulership and the position of the ruler within the complex interaction between the human and celestial realms. As we have seen in The expedition of King Wu, a sudden turn of history can be attributed to some supernatural intervention that affects the smooth operation of the apparatus of government. This novel also shows how the functioning of the state is dependent on the attitudes of the ministers and their moral courage.

In our discussion of The expedition of King Wu we have focused mainly on the role of women as catalysts of the dramatic intrigue, and the role of the ministers. We will conclude this section on kingship, demons, and gods with a brief analysis of the dénouement of this story, in which the destructive interference of Daiji is repressed. In the short account of this story in The expedition of King $W u$ this episode is summarized rather than expounded in detail, but it is much more elaborately narrated in a novel of the seventeenth century entitled Creation of the gods. ${ }^{19}$ This novel is based on the same story as The expedition of King Wu, and it follows the chronology of the scenes of the account quite accurately. However, here the various scenes and intrigues are much more elaborately described and enacted, to heighten the dramatic effect and to make full use of the potential of fictional narration. As a result, whereas The expedition of King Wu numbers about sixty pages in the English translation, the novel Creation of the gods numbers about nine hundred. In contrast to the shorter version, in the elaborate version the struggle to eliminate the emperor and his evil concubine is related in great detail.

Apart from the extensive descriptions of the battles between the armies of Emperor Zhou and his opponent King $\mathrm{Wu}$, the episode of the expedition provides interesting information about the visions of rulership, which are enclosed in the narrative logic and explicated especially at the end. These visions are related to the figure of Jiang Ziya, a seemingly common person who, however, possesses supernatural powers and is in touch with the immortals. He lives as a good-for-nothing for some time, until his prognostic talents are discovered and he is invited to the court of the emperor. When he receives the assignment to construct a sumptuous palace in a very short time, he flees court and settles in the province as a humble fisherman. One day he is 'discovered' as the person who is predestined to join King Wu's army and lead it to victory. After he is led before King Wu and appointed as his chief minister, he assumes 
his task as the commander of the rebellious army, making use of his miraculous powers.

The war between the armies of the emperor and King $\mathrm{Wu}$ is apparently conducted by normal human soldiers, but the actual battles are fought with extraordinary means. Some of the great warriors are equipped with magical weapons, which enable them to capture even the strongest enemies. The battles are decided not only by physical strength and tactical acumen, but most often by the magical powers of the heroes on the two sides. The generals of the two armies enlist the help of various holy figures and immortals who support their cause and who use their powers against equally miraculous opponents. The war is thus depicted as a struggle between earthly and human parties, which are inextricably linked to their counterparts in the supernatural realm, from whom the outcome in the end depends. The war is a manifestation of a much greater struggle of celestial elements who strive to determine the course and effectuation of fate, which finds its manifestation in the new constellation on earth. The war is not just a fight on two fronts, earthly and celestial; it involves an inseparable combination of human and celestial efforts to foster the fulfilment of destiny.

It is Jiang Ziya who is capable of mobilizing and combining the many components of the struggle, like a conductor of a huge and diverse orchestra, which demands all his ingenuity and strength of will. It is also Jiang Ziya who comprehends the nature and the many dimensions of the struggle, and its connection with the celestial forces. When he is asked by a general how he can be so ungrateful as to rebel against the emperor, he answers:

You've got it all wrong, General! It's often said that 'The kingdom does not belong to one person; it's owned by all.' The will of Heaven is subject to change, and it always favors the virtuous. In ancient times, Yao offered his throne to Shun, Shun to $\mathrm{Yu}$, and Yu to his descendants. His last successor, however, lost the Xia Dynasty, and the founder of the new was favoured by Heaven for his great virtue. It's hard to imagine that his descendant, Zhou, is so wicked. Heaven has abandoned him, and the people hate him. We have come as a united front to save the people in distress. We will carry out punishment as Heaven has willed. We cannot recognize him as a king. ${ }^{20}$ 
This appeal to the will of Heaven, as the manifestation of destiny, is supported by the people, who agree that the tyrant should be brought down. Jiang Ziya confirms that it is the duty of a king to rule the people by Constitution according to the will of Heaven, caring for his subjects as a father for his children.

The question of Jiang Ziya's position and self-justification is, of course, connected with the behavioural code of the minister, who owes loyalty to the emperor. However, the novel is quite clear about the proper conduct in these circumstances: The king has estranged the good ministers from the administration; he has 'appointed bootlickers, ruined ethical relationships and disdained virtue'. Loyal ministers are the 'trunk and branches' of the nation, but the king has maltreated them and 'severed the ethical relationship between a king and his ministers.' ${ }^{21}$ This behaviour resulted in a loss of honesty, which is the 'foundation of human existence' and 'the most powerful weapon a king needs to rule his nation'; ${ }^{22}$ in the unjust application of the law; and in extravagant expenses and the squandering of natural resources and national wealth. Jiang Ziya: 'Since ancient times no ruler living in extravagance has been able to keep his dynasty from destruction. The saints have warned us over and over again. We must treasure virtue rather than pearls or jade. ${ }^{23}$ It is the connection with virtue that is the essence of kingship. Still, in spite of Zhou's obvious abuses, King Wu is reluctant to let ministers fight directly against the emperor, as this would be contrary to the code of proper conduct. In the end Zhou commits suicide by setting the palace aflame with himself in it.

The dilemma of the justification of revolt, linked to the inevitability of fate, is raised again when Daiji is finally captured. The clever fox-spirit, in her anguish, argues that: 'we've done our best to ruin the Shang Dynasty. How can you be ungrateful?' ${ }^{24}$ Of course, the immortal Nü Wa, who holds her captive, cannot deny that she has been a quite efficient instrument of fate, speeding up the coming of a new era. However, he retorts: 'I sent you to help King Zhou lose his kingdom; it was just as fate had destined. But you were too cruel and ruthless. You murdered so many loyal ministers and innocent people. Your crimes are too great and you must be dealt with according to the law.'25 This brief conversation nicely sums up the dilemma embedded in the Chinese vision of the macrocosmic and microcosmic mechanisms: Every creature has

$\begin{array}{ll}21 & \text { Ibid., 423. } \\ 22 & \text { Ibid. } \\ 23 & \text { Ibid., 444. } \\ 24 & \text { Ibid., 432. } \\ 25 & \text { Ibid. }\end{array}$


his or her role in the realization of fate, but each has his or her own capacities, powers, functions, and responsibilities; and, it seems, within these restrictions each has the possibility to make moral choices, to execute the tasks assigned to him or her either according to moral premises or according to his or her particular, vicious inclinations. Overall, events are predestined and determined by fate, but since almost nobody knows the outcome, there remains a vast space in which each creature has to play his or her part to realize his or her individual fate and contribute to the destiny of the universe as a whole.

Within these mechanisms, virtue is a major constituent force. This vital asset has now, in this turbulent period, accumulated in King $\mathrm{Wu}$, who is so mildhearted, even diffident, that he is rather ineffectual in the struggle, which is totally controlled by Jiang Ziya. He wants to spare all the mean enemies, he wants to keep up decorum in spite of the complete implosion of the system, and he is almost over-compassionate. In the end, when the enemy is defeated, he almost spoils everything by refusing to occupy the now vacant throne, out of sheer politeness. Only after the people have pledged their support and the minister has argued 'You will have failed in your original intention to save the people from distress, and instead of peace and happiness, they will only suffer more, ${ }^{26}$ can $\mathrm{Wu}$ be persuaded to become emperor. Subsequently, the organization of the empire is rearranged: all provinces are assigned to the good and loyal notables, according to their various ranks, and the forefathers of $\mathrm{Wu}$ are retrospectively raised to the status of emperor. Jiang Ziya is officially sworn in as the head of all the dukes, holding the yellow axe and the white sceptre.

After this thorough reorganization of the empire, only one task remains: the deification of those who have fallen in the struggle for the just cause:

As fate had destined, many fairies and ordinary generals were killed along the way. Before we left, we put the List of Creations in the Terrace of Creation, but now the souls of the deceased need a fixed place to stay. So I must ask leave from you to go to Mount Kunlun to see my master. I will ask him for the jade spells, seal, and golden-leaf booklet, so that I may deify the deceased upon my return. ${ }^{27}$

Jiang Ziya travels to the Jade Emptiness Palace to request permission for the deification from the Heavenly Primogenitor, which is granted without objection. A long list is given of the new deities, spirits, and immortals, with their

\footnotetext{
26 Ibid., 446.

27 Ibid., 453.
} 
tasks indicated, to complete the reorganization of the heavenly realm, which complements the change of dynasty on earth.

A historical transition is now concluded, which had set in with the dream of the emperor and the penetration of a fox-spirit into the heart of the empire corrupting the emperor and concomitantly corrupting the functioning of the state. Only after the intruder has been eliminated can order be restored by a far-reaching purification of the administrative apparatus and the substitution of the immoral emperor. This can be achieved only by a person who embodies virtue and who is supported by the celestial framework and the mechanisms of destiny. And, of course, by the indispensable help of an extremely gifted minister.

\section{Concluding Remarks}

In this chapter we have become acquainted with three exemplary (semi-)historical rulers, Vikramaditya, Harun al-Rashid, and $\mathrm{Wu}$, who are situated in the core of fictional narrative corpuses that structure representations and discourse of authority. They are all three presented as model rulers whose power is partly derived from their ability to exorcise demons and spells that have penetrated into the lives of the common subjects, making them miserable or holding them imprisoned in some kind of enchantment. This ability is not derived from their inherent power or particular abilities, but rather from their identification with the divine schemes and the effectuation of fate. Their privileged position and their special relationship with the Divine are based not on force, but rather on virtuousness and justice. Moreover, they are sent by Providence not to embody earthly glory or even celestial magnificence, but rather to humbly serve the interests of the populace and to remedy their suffering. They owe their illustrious place in history to this ability, rather than to military prowess or royal splendour.

It is remarkable that none of these kings is represented as a monolithic, heroic, symbol of power. Although they are idealized and provided with extraordinary talents, they are reluctant to transform these talents into power, and prefer to display justice, comprehension, ingenuity, and clemency. To some extent they are anti-heroes, who have reached their positions despite themselves, as if forced by irresistible forces to assume their responsibilities. They are also all three helped by formidable ministers, who represent the pragmatic and executive component of power supplementing the symbolic and moral power of the king. Whereas the king represents the 'soft' ingredients of kingship, the ministers personify the active and 'hard' ingredients, producing an 
efficient mixture of power and legitimacy. This confirms the idea that authority is presented as being inevitably composite, as we have seen in Chapter One as well. Authority is vested not in one person only; it is construed upon a dialogic situation that includes several parties, and upon the two main components of the figure of the king.

The texts treated in this chapter show formal and conceptual similarities with the texts analysed in Chapter One. The thematic contrasting of silence and narration, the use of frames, and the serializing of exemplary tales are procedures used in various narratives. But we also find recurrent motifs, such as dissimulation, the central role of women in the fictional intrigue, disguise, the appeals by ministers, etc. These narrative elements and strategies all serve to destabilize the monolithic discourse of power, indicating that authority is inherently complex, based on both heavenly support and human endeavour, and embodied by princes who are not confined to their elevated, symbolic, persona, but also have more common alter egos. The conjuring of demonic forces is a test, not only of their courage and strength, but primarily to show their compassion and self-sacrifice. They may derive their authority from the Divine, but it is granted to them for their willingness to serve the people, whose condition measures the quality of rulership. 